\title{
Synthesis, Pharmacology, and Cell Biology of sn-2-Aminooxy Analogues of Lysophosphatidic Acid
}

\author{
Joanna Gajewiak ${ }^{\dagger}$, Ryoko Tsukahara $^{\ddagger}$, Yuko Fujiwara ${ }^{\ddagger}$, Gabor Tigyi ${ }^{\ddagger}$, and Glenn D. \\ Prestwich $^{\dagger}$ \\ Glenn D. Prestwich: gprestwich@pharm.utah.edu \\ †Department of Medicinal Chemistry, The University of Utah, 419 Wakara Way, Suite 205, Salt \\ Lake City, Utah, 84108-1257 \\ ‡Department of Physiology, College of Medicine, University of Tennessee Health Science Center, \\ Memphis, Tennessee 38163
}

\begin{abstract}<smiles>[R]C(=O)OCC(O)COP(=O)(O)O</smiles>

(S)-solketal

sn-2-AO-LPA

An efficient enantioselective synthesis of sn-2-aminooxy (AO) analogues of lysophosphatidic acid (LPA) that possess palmitoyl and oleoyl acyl chains is presented. Both sn-2-AO LPA analogues are agonists for the $\mathrm{LPA}_{1}, \mathrm{LPA}_{2}$, and $\mathrm{LPA}_{4} \mathrm{G}$-protein-coupled receptors, but antagonists for the $\mathrm{LPA}_{3}$ receptor and inhibitors of autotaxin (ATX). Moreover, both analogues stimulate migration of intestinal epithelial cells in a scratch wound assay.
\end{abstract}

Lysophosphatidic acid (1- or 2-acyl-sn-glycerol 3-phosphate, LPA) is a deceptively simple ligand that elicits a rich palette of biological responses, including platelet aggregation, promotion of cell survival, and cell migration. ${ }^{1,2}$ The most important source of LPA is the action of lysophospholipase D (lysoPLD), or autotaxin (ATX), on lysophosphatidyl choline (LPC). ${ }^{3}$ ATX is one of the 40 most upregulated genes in invasive cancers ${ }^{4}$ and has been implicated in cell motility and tumor invasion, metastasis, and neovascularization. ${ }^{3}$ LPA signals through the activation of specific receptors, which in turn leads to distinct cellular events depending on the receptor subtype expressed by the targeted cell. Cell surface LPA receptors belong to the membrane $\mathrm{G}$ protein-coupled receptors (GPCRs) protein family, and five mammalian LPA GPCRs have been characterized: $\mathrm{LPA}_{1}, \mathrm{LPA}_{2}, \mathrm{LPA}_{3}, \mathrm{LPA}_{4}$, and $\mathrm{LPA}_{5} \cdot{ }^{1,5-8}$

Modification of LPA may involve either the phosphate head group, the glycerol backbone, or the acyl groups, leading to many changes in biological activity. ${ }^{9-12}$ Only a few analogues of LPA feature modifications only at the $s n-2$ position (Figure 1). For example, OMPT (1oleoyl-2- $O$-methyl-rac-glycerophosphothioate), in either the racemic ${ }^{13}$ or optically pure ${ }^{14}$ forms, are potent agonists for the $\mathrm{LPA}_{3}$ receptor. The HE-LPA (hydroxyethoxy-LPA)

\footnotetext{
(C) 2008 American Chemical Society

Correspondence to: Glenn D. Prestwich, gprestwich@pharm. utah.edu.
}

Supporting Information Available: Experimental detailes for the synthesis and characterization of new compounds and protocols for biological assays. This material is available free of charge via the Internet at http://pubs.acs.org 
analogues ${ }^{15}$ are modest agonists for $\mathrm{LPA}_{3}$ with 10 -fold lower potency than the parent oleoyl LPA. Finally, the $s n-2-F$ LPA analogs ${ }^{16}$ show relatively weak agonist activity for all LPA receptor isoforms.

Recently, series of novel cytotoxic phospholipids, LPA-like serine amide phosphates (SAPs) were synthesized and demonstrated to be low micromolar inhibitors of prostate tumor cell proliferation. ${ }^{17}$ The key element of this structure was the presence of a primary amine at the $s n-2$ position. Rather than introduce a strongly basic group into the LPA structure, our approach was to introduce the less basic but strongly nucleophilic aminooxy (AO) group at the $s n-2$ position. AO compounds are frequently employed as potent inhibitors of pyridoxal-5-phosphate-dependent enzymes, such as aminotransferases, serine hydroxymethyltransferase, tyrosine decarboxylase, cystationase, and ornithine decarboxylase, whereby the aminooxy moiety forms a stable oxime with the aldehyde group present on the cofactor. ${ }^{18-22} \mathrm{AO}$ analogues have also been demonstrated to function in vitro as potent antimalarial agents. ${ }^{23}$

We used the Mitsunobu reaction to introduce the AO functionality in stereocontrolled manner using straightforward protection and deprotection steps, thus elaborating an efficient synthetic approach to produce enantiomerically pure sn-2 AO-LPA analogues. Herein we describe the asymmetric total syntheses of two sn-2-AO LPA analogues, as well as evaluation in pharmacological, biochemical, and cell biological assays that reveal unexpected agonist and antagonist activities.

\section{Synthesis}

The synthesis of $s n$-2-AO LPA started with benzylation of (S)-solketal (1) (Scheme 1), followed by removal of the isopropylidene with an acidic ion-exchange resin, ${ }^{24,25}$ to give intermediate diol 2. Next, TBDMS was introduced ${ }^{26,27}$ at the primary hydroxyl group at $0-3$ ${ }^{\circ} \mathrm{C}$ to produce precursor 3 , which was transformed via a Mitsunobu reaction at $0{ }^{\circ} \mathrm{C}^{28,29}$ into phthalimide derivative $\mathbf{4}$ with clean inversion of configuration at the stereogenic center. Hydrazine monohydrate treatment of compound $4^{29}$ afforded the aminooxy intermediate 5 in quantitative yield. The enantiomeric purity of the aminooxy compound was verified by conversion to the $(R)$-Mosher amide; ${ }^{30}{ }^{19} \mathrm{~F}$ NMR showed that intermediate 5 to have $>95 \%$ enantiomeric purity. Next, the aminooxy group of $\mathbf{5}$ was reprotected with Boc to produce derivative 6, and the benzyl ether was hydrogenolyzed to yield alcohol 7 in over $95 \%$ yield. Compound 7 was converted to the palmitoyl (8a) and oleoyl (8b) esters using carbodiimide chemistry, and deprotection of the silyl ether with $\mathrm{Bu}_{4} \mathrm{NF}^{26}$ in THF smoothly produced intermediates $9 \mathbf{a}$ and $9 \mathbf{b}$ in high yields.

In attempting to remove both methyl and Boc protecting groups, neither an excess of $\mathrm{TMSBr}$ nor TMSBr followed by TFA, nor anhydrous $\mathrm{HCl}$ gave any desired product. Finally, each ester 11a and 11b was treated with BSTFA $(N, O-$

bis(trimethylsilyl)trifluoroacetamide) ${ }^{32}$ and TMSBr for $1 \mathrm{~h}$ under strict anhydrous condition in $\mathrm{CH}_{2} \mathrm{Cl}_{2}$, followed by addition of a wet $\mathrm{CH}_{2} \mathrm{Cl}_{2}(0.5 \%$ water) with stirring for $45 \mathrm{~min}$. The crude compounds were then dried in vacuo, and $10 \%$ aq. methanol was added, which resulted in simultaneous deprotection of Boc group and the phosphate methyl esters. The desired compounds 12a and 12b (Scheme 2) were obtained in homogeneous form in good yields after filtration of each methanol solution through a Whatman PTFE Syringe Filter.

\section{Pharmacology of AO-LPA Analogues on LPA Receptors}

The pharmacological properties of AO-LPA analogues 12a and 12b were evaluated on $\mathrm{LPA}_{1-3}$ GPCRs in the McArtl rat hepatoma cell line RH7777, and on $\mathrm{LPA}_{4}$ in $\mathrm{CHO}$ cells. 
Table 1 summarizes these data, which show that both palmitoyl and oleoyl sn-2-AO LPA analogues are agonists for the $\mathrm{LPA}_{1}, \mathrm{LPA}_{2}$, and $\mathrm{LPA}_{4}$ G-protein-coupled receptors but are antagonists for the $\mathrm{LPA}_{3}$ receptor. The oleoyl analogue 12b is the most potent $(382 \mathrm{nM})$ and also a full agonist for $\mathrm{LPA}_{2}$. This analogue is also the most potent $(56 \mathrm{nM})$ partial antagonist for $\mathrm{LPA}_{3}$. Both 12a and 12b inhibit recombinant ATX activity at $10 \mu \mathrm{M}$ with potencies similar to those of LPA itself (see Supporting information).

\section{Activity of AO-LPA Analogues on Cell Migration}

The AO-LPA analogues 12a and 12b enhanced rate cell migration in IEC-6 human intestinal endothelial cells in a scratch wound assay (Figure 2). In this assay, the rate of cell migration is measured by the time it takes for the cells to close a gap in the cell monolayer created by "scratching" the monolayer with a pipet tip. This effect is congruent with the agonist activity toward the $\mathrm{LPA}_{2}$ receptor, which is coupled to the Rho/Rac1 small GTPases and augments cell migration and cell survival. ${ }^{33}$

The replacement of the $s n-2$ hydroxy group of LPA with the more nucleophilic aminooxy function afforded AO-LPA analogues 12a and 12b. This small structural change has profound effects on the receptor pharmacology and cell biology of the analogues. Instead of the pan-receptor agonist activity exhibited by LPA, 12a and 12b are weak agonists for LPA and $\mathrm{LPA}_{4}$, strong agonists for $\mathrm{LPA}_{2}$, and antagonists for the $\mathrm{LPA}_{3}$. This mixed profile isoform selectivity makes them useful research tools for cell biology. Moreover, their ability to enhance migration of intestinal epithelial cells in vitro suggests therapeutic potential for repair of the gastrointestinal epithelium in vivo.

\section{Supplementary Material}

Refer to Web version on PubMed Central for supplementary material.

\section{Acknowledgments}

This work was supported by the National Institutes of Health (NS29632 to G.D.P. and HL61469 and CA921160 to G.T.)

\section{References}

1. Mills GB, Moolenaar WH. Nat. Rev. Cancer. 2003; 3:582-591. [PubMed: 12894246]

2. Feng L, Mills GB, Prestwich GD. Expert Opin. Ther. Pat. 2003; 13:1619-1634.

3. Hama K, Aoki J, Fukaya M, Kishi Y, Sakai T, Suzuki R, Ohta H, Yamori T, Watanabe M, Chun J, Arai H. J. Biol. Chem. 2004; 279:17634-17639. [PubMed: 14744855]

4. Euer N, Schwirzke M, Evtimova V, Burscher, Jarsch M, Tarin D, Weidle U. Anticancer Res. 2002; 22:733-740. [PubMed: 12014644]

5. Kotarsky K, Boketoft Å, Bristulf J, Nilsson NE, Norberg Å, Hansson S, Owman C, Sillard R, LeebLundberg LMF, Olde B. J. Pharmacol. Exp. Ther. 2006; 318:619-628. [PubMed: 16651401]

6. Luquain C, Sciorra V, Morris A. TIBS. 2003; 28:377-383. [PubMed: 12878005]

7. Noguchi K, Ishii S, Shimizu T. J. Biol. Chem. 2003; 278:25600-25606. [PubMed: 12724320]

8. Umezu-Goto M, Tanyi J, Lahad J, Liu S, Yu S, Lapushin R, Hasegawa Y, Lu Y, Trost R, Bevers T, Jonasch E, Aldape K, Liu J, James RD, Ferguson CG, Xu Y, Prestwich GD, Mills GB. J. Cell. Biochem. 2004; 92:1115-1140. [PubMed: 15258897]

9. Jiang G, Xu Y, Fujiwara Y, Tsukahara T, Tsukahara R, Gajewiak J, Tigyi G, Prestwich GD. ChemMedChem. 2007; 2:679-690. [PubMed: 17443831]

10. Xu Y, Aoki J, Shimizu K, Umezu-Goto M, Hama K, Takanezawa Y, Yu S, Mills GB, Arai H, Qian L, Prestwich GD. J. Med. Chem. 2005; 48:3319-3327. [PubMed: 15857137] 
11. Prestwich GD, Xu Y, Qian L, Gajewiak J, Jiang G. Biochem. Soc. Trans. 2005; 33:1357-1361. [PubMed: 16246118]

12. Gajewiak J, Tsukahara R, Tsukahara T, Fujiwara Y, Yu S, Lu Y, Mills GB, Tigyi G, Prestwich GD. Chem. Med. Chem. 2007; 2:1789-1798. [PubMed: 17952880]

13. Hasegawa Y, Erickson JR, Goddard GJ, Yu S, Liu S, Cheng KW, Eder A, Bandoh K, Aoki J, Jarosz R, Schrier AD, Lynch KR, Mills GB, Fang X. J. Biol. Chem. 2003; 278:11962-11969. [PubMed: 12554733]

14. Qian L, Xu Y, Hasegawa Y, Aoki J, Mills GB, Prestwich GD. J. Med. Chem. 2003; 46:5575-5578. [PubMed: 14667211]

15. Qian L, Xu Y, Arai H, Aoki J, McIntyre TM, Prestwich GD. Org. Lett. 2003; 5:4685-4688. [PubMed: 14627415]

16. Xu Y, Qian L, Prestwich GD. J. Org. Chem. 2003; 68:5320-5330. [PubMed: 12816494]

17. Gududuru V, Hurh E, Durgam GG, Hong SS, Sardar VM, Xu H, Dalton JT, Miller DD. Bioorg. Med. Chem. Lett. 2004; 14:4919-4923. [PubMed: 15341952]

18. Baskaran N, Prakash V, Savithri HS, Radhakrishnan AN, Appaji Rao N. Biochemistry. 1989; 28:9613-9617. [PubMed: 2611250]

19. Beeler T, Churchich JE. J. Biol. Chem. 1976; 251:5267-5271. [PubMed: 8458]

20. Rosenthal GA. Eur. J. Biochem. 1981; 114:301-304. [PubMed: 7215357]

21. Rosenthal GA. Life Sci. 1997; 60:1635-1641. [PubMed: 9129118]

22. Worthen DR, Ratliff DK, Rosenthal GA, Trifonov L, Crooks PA. Chem. Res. Toxicol. 1996; 9:1293-1297. [PubMed: 8951231]

23. Berger B. Antimicrob. Agents Chemother. 2000; 44:2540-2542. [PubMed: 10952611]

24. Ryan M, Smith MP, Vinod TK, Lau WL, Keana JFW, Griffith OH. J. Med. Chem. 1996; 39:43664376. [PubMed: 8893831]

25. Heeb NV, Nambiar KP. Tetrahedron Lett. 1993; 34:6193-6196.

26. Corey EJ, Venkateswarlu A. J. Am. Chem. Soc. 1972; 94:6190-6191.

27. Zhang D, Poulter CD. J. Am. Chem. Soc. 1993; 115:1270-1277.

28. Mitsunobu O, Wada M, Sano T. J. Am. Chem. Soc. 1972; 94:679-680.

29. Bailey S, Harnden MR, Jarvest RL, Parkin A, Boyd MR. J. Med. Chem. 1991; 34:57-65. [PubMed: 1846922]

30. Dale JA, Dull DL, Mosher HS. J. Org. Chem. 1969; 34:2543-2549.

31. Carpino LA, Giza CA, Carpino BA. J. Am. Chem. Soc. 1959; 81:955-957.

32. Erickson, JR. United States Patent. 6,380,177. 2002.

33. Deng W, Shuyu E, Tsukahara R, Valentine W, Durgam G, Gududuru V, Balazs L, Manickam B, Arsura M, Vanmiddlesworth L, Johnson L, Parrill A, Miller D, Tigyi G. Gastroenterology. 2007; 132:1834-1851. [PubMed: 17484878] 
<smiles>[R]C(=O)OC[C@@H](O)COP(=O)(O)O</smiles>

parent LPA<smiles>[R]C(=O)OC[C@@H]([R])COP(=O)(O)O</smiles>

R: $-\mathrm{OCH}_{3}(\mathrm{OMPT}$ analog) $-\mathrm{F}$ $-\mathrm{OCH}_{2}-\mathrm{CH}_{2}-\mathrm{OH}$ (HE-LPA analog)

Figure 1.

Structures of LPA, OMPT, HE-LPA, and SAP. 


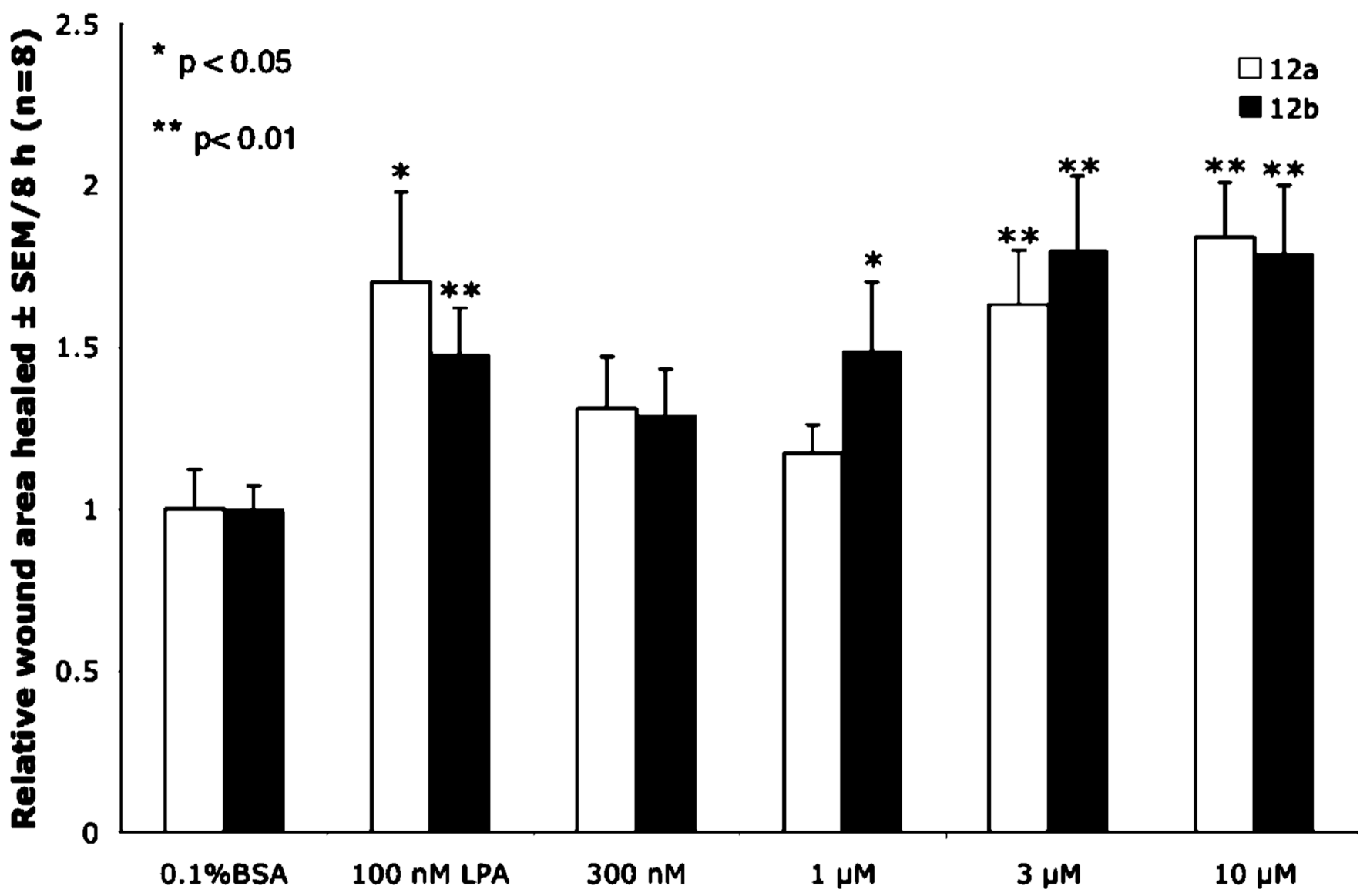

Figure 2.

Compounds 12a and 12b promote cell migration in a scratch wound assay using IEC-6 cells. The basal rate of cell motility was measured in the presence of $0.1 \%$ BSA vehicle for stabilizing the LPA or LPA analogue, and the maximal LPA-induced response was evoked by treatment with $100 \mathrm{nM} \mathrm{LPA}$. The bars represent the mean rate of cell migration in scratch wounds treated with different concentrations of 12a and $\mathbf{1 2 b}$. The results represent the rate of migration over an $8 \mathrm{~h}$ period and the mean of 8 experiments. 

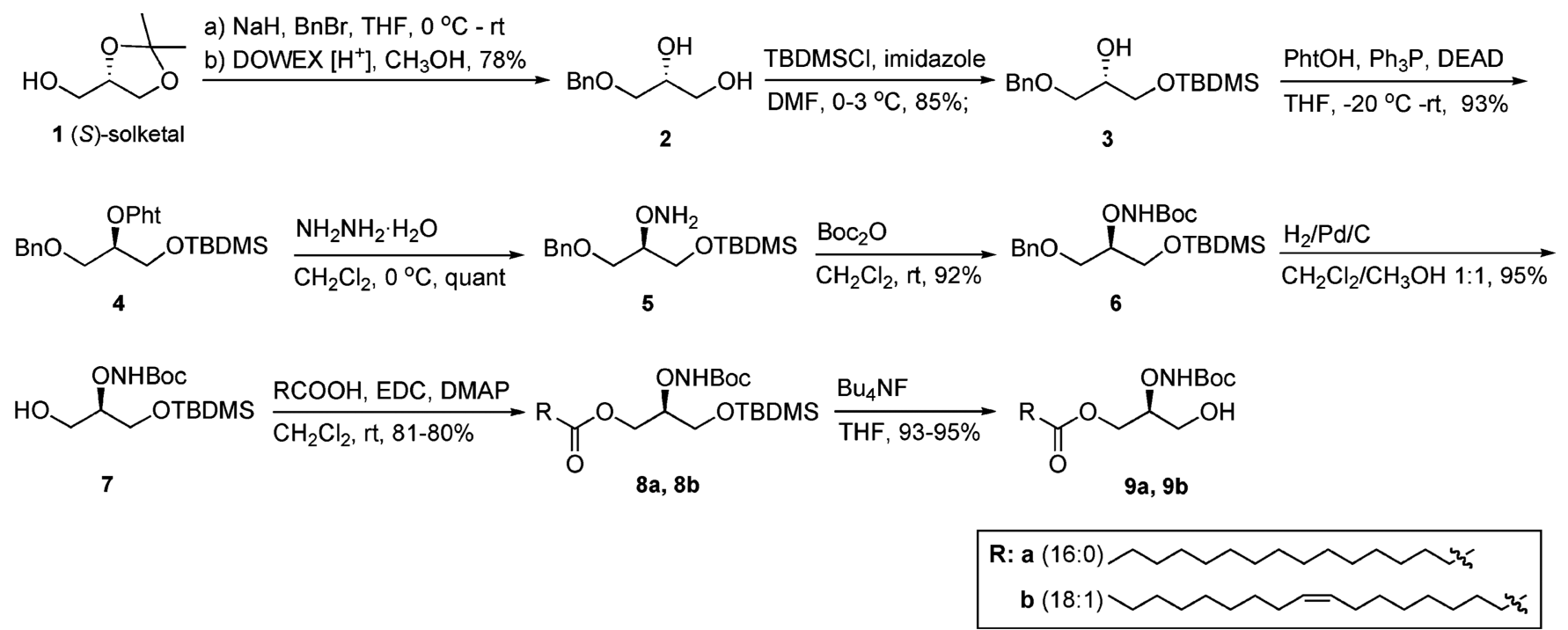

Scheme 1.

Synthesis of $s n-2-A O-L P A$ Intermediates $9 \mathbf{a}$ and $\mathbf{9 b}$ 


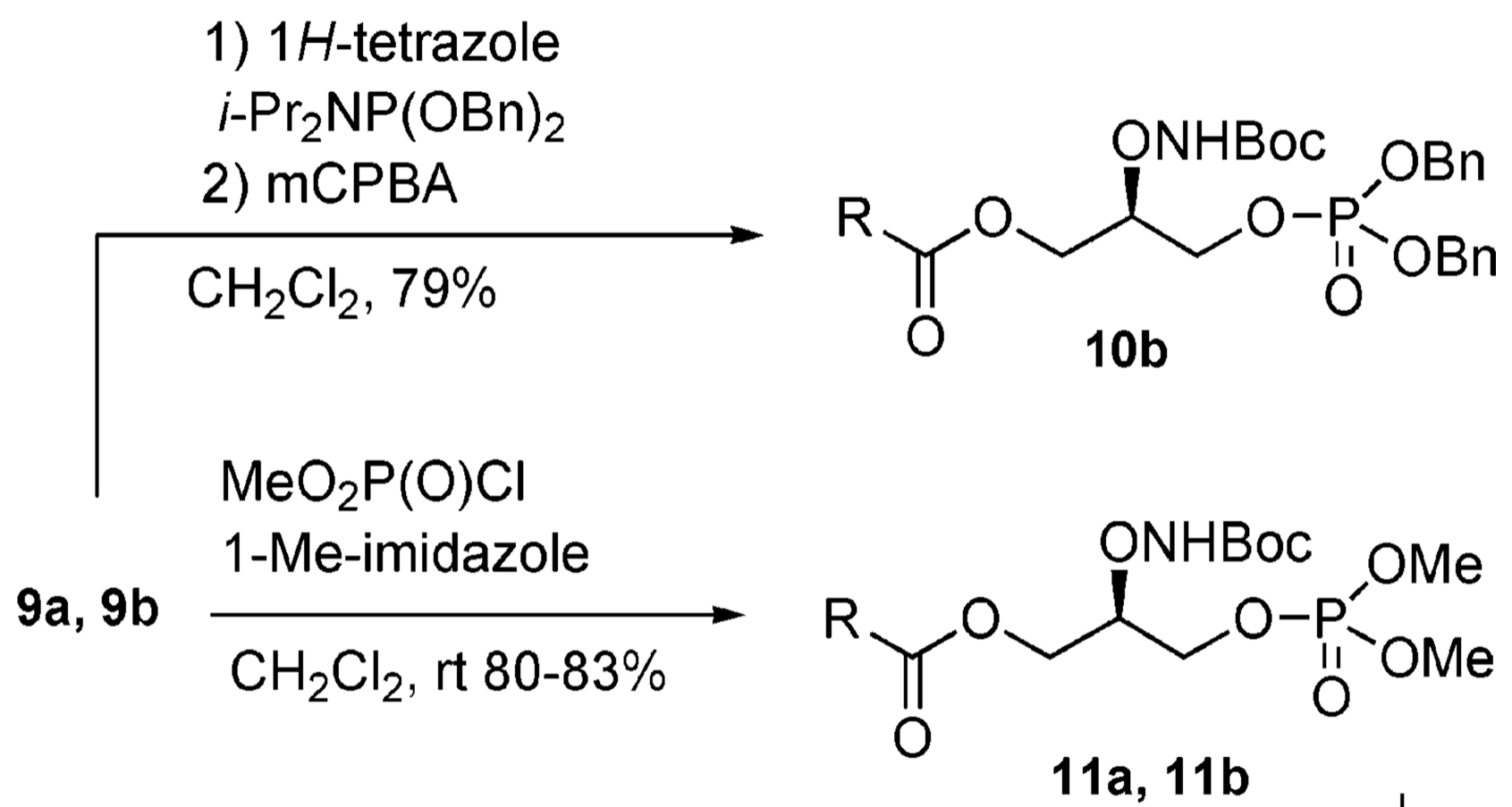<smiles>[R]C(=O)OC[C@@H](N)COP(=O)(O)O</smiles>

$12 a, 12 b$
1) BSTFA, TMSBr, $\mathrm{CH}_{2} \mathrm{Cl}_{2}$ anh.

2) wet $\mathrm{CH}_{2} \mathrm{Cl}_{2}$

3) $10 \% \mathrm{CH}_{3} \mathrm{OH}, 85-86 \%$

Scheme 2.

Conversion of Intermediates to $s n-2-A O-L P A$ Analogues 12a and 12b 
